\title{
Adherence to Antiretroviral Therapy in HIV-Positive Patients in Ethiopia: Review
}

\section{Serawit Deyno* and Alemayehu Toma}

Pharmacology Unit, School of Medicine, Hawassa University, Hawassa, Ethiopia

*Corresponding author: Serawit Deyno, Pharmacology Unit, School of Medicine, Hawassa University, Hawassa, Ethiopia, Tel: 251-912799841; Email:dserawit@gmail.com

Rec date: May 21, 2014; Acc date: Jun17, 2014; Pub date: Jun19, 2014

Copyright: (C) 2014 Deyno S, et al. This is an open-access article distributed under the terms of the Creative Commons Attribution License, which permits unrestricted use, distribution, and reproduction in any medium, provided the original author and source are credited.

\begin{abstract}
Background: Highly active antiretroviral therapy (HAART) offered HIV-positive individuals tremendous lifesustaining benefits. The benefits are sustainable only through optimal adherence. This systematic review was conducted to synthesize the available studies in order to determine average adherence, identify variables associated with adherence and shed light on the design and improvement of adherence studies and interventions.

Method: Studies were selected from electronic databases (Pubmed, Hinari, Google scholar) using HAART or Highly active antiretroviral therapy and adherence [Ethiopia] as search terms. Each study was summarized by using format containing: characteristics of the study, sample size, study design and measures of adherence, factors associated with adherence, reasons for missing dose.

Result: A total of 17 studies: 16 cross-sectional and 1 prospective study reporting adherence to HAART in Ethiopian HIV-positive patients were identified in our search items. Almost all of adherence to HAART studies conducted in Ethiopia used cross-sectional study design with self-report as adherence measurement. Though from the lowest evidence design the adherence rate in Ethiopia were higher than many developed countries report. Social support is major positive predictor of adherence to HAART while depression and substance abuse were negative predictors'.

Conclusion: We demonstrated a better self-reported adherence to HAART in Ethiopian HIV-positive patients. However rate and determinants of HAART in Ethiopian HIV-positive patients are poorly defined. The type of study design used and the use of self-report (subjective measure) in adherence assessment made adherence to HAART unexplored in Ethiopia. Further studies should be conducted using prospective cohort and interventional study design using varying methods of adherence measurement.
\end{abstract}

Keywords: Adherence; HAART; Self report; Pill count; HIVpositive; Ethiopia

\section{Background}

Highly active antiretroviral therapy (HAART) is a breakthrough and celebrated in the reduction of mortality and in the improvement of quality of life of people living with HIV/AIDS (PLWHA). On its introduction in 1996, antiretroviral therapy (ART) offered HIV positive individuals tremendous life-sustaining benefits and is most likely the single most dramatic development yet in the treatment of HIV. This evidence has been well-documented in many papers [1-4].

When taken consistently and strictly as directed, the benefits of ART include increased CD4 cell counts [5,6], decreased viral load, and decreased probability of progression to full-blown AIDS and death, and improved quality of life $[3,4]$. Consistent use of antiretroviral therapy (ART) therefore suppress viral replication and reduce the likelihood of development of drug resistant viral strain and also prevents further viral destruction of the cellular immune system $[7,8]$.

Even though adherence to ART is one of the few potentially alterable factors determining outcomes for patients with HIV, nonadherence to ART is common in all groups of treated individuals $[5,9]$.
Medication adherence, particularly for complex regimens such as HAART, is a complex behavior, requiring patients to remember multiple medications and dosing schedules. Patient failure to follow the ART regimen can lead to the development of treatment-resistant strains of the virus and poorer health outcomes $[10,11]$.

There are multiple factors that influence adherence: patient factors (e.g. socioeconomic, educational status etc.), treatment regimen characteristics, disease characteristics, and patient-provider relationship, patient's clinical, social, psychological, and behavioral variables are among the most important factors that influence adherence and are potentially modifiable variable [12-14]. The search for this potentially modifiable variable correlation with adherence is the main theme in adherence studies. Adherence is a very dynamic varying among many population groups as result of many modifiable variables.

Studies have evaluated adherence to HAART and its associated factors/variables among Ethiopian HIV-positive patients. However these studies reported different adherence rate and determinants. Findings from different studies vary depending on how adherence was measured, the characteristics of the samples, and the remaining variables analyzed. We have learned the importance of having conclusive evidence by combing available studies. A systematic review 
identifying and explaining these discrepancies is required for designing further studies and interventional strategies. The objective of this study is to carry out systematic review of HAART adherence in Ethiopian HIV-positive populations and to synthesize studies in order to determine average adherence and identify the variables associated with adherence. This systematic review will also shed light on the design and improvement of adherence to HAART studiesand interventions meant for improving adherence.

\section{Methods}

\section{Data search}

The studies were searched from electronic databases (Pubmed, Hinari, Google scholar). Words such as [HAART OR highly active antiretroviral therapy] and adherence and[Ethiopia], and antiretroviral therapy and adherence and [Ethiopia] are used as search terms. All studies included in the study are those written in English language. Other search terms that reflect adherence (e.g. compliance, pill counts) are also interchangeably used with adherence. Reference list of originally found article were also searched for eligible article to be included.

\section{Study selection: Inclusion and exclusion criteria}

Studies were included in the review if they aimed to evaluate adherence to HAART in a Ethiopian sample, had a cross-sectional or cohort design, measured adherence and/or reported factors associated with adherence and operationally defined adherence as intake of $>90 \%$ or $95 \%$ of the medication prescribed $[15,18]$.

\section{Data extraction}

Data extraction was conducted using a standardized format. Data was summarized on format containing characteristics of the study, sample size, study design and measures of adherence, factors associated with adherence, reasons for missing dose. When more than one adherence measurement was used (e.g. unannounced pill count and self -report), data from all methods were collected and compared.

\section{Findings}

\section{Characteristics of adherence to HAARRT studies conducted in Ethiopia}

Seventeen studies assessing adherence rate and determinates of HAART in Ethiopia in HIV-positive patient were found: Thirteen studies on adults $[12,13,15,17,19-26]$ while four studies were conducted in children [14,18,27,28]. All of these studies have reported either adherence rate and/or determinants' of adherence to antiretroviral therapy. The studies were reported between 2006 to 2014. The sample size extends from the minimum 204 children [27] to a maximum of 510 adults [19]. Four of them are qualitative studies focused on reporting factors associated with adherence $[23,24,26,28]$. Four studies were conducted in children $[14,18,27,28]$ while 13 studies were conducted in adults which are powered to determine adherence rate and its determinants. One study used prospective study design with 3 months follow up duration. All other studies used crosssectional study design which is the lowest in the evidence pyramid of studies. Details of the study characteristic were presented in Table 1 and Table 2 below.
The entire studies defined optimal adherence as greater $95 \%$ and used this definition in their studies. Adherence was measured across various time periods: the previous day, the previous 3 day and the previous seven day. The previous seven day was however used in estimating of the adherence rate of the studies in the included studies.

Self-report for adults or caregivers report for children was used for the assessment of the entire reviewed studies. However two studies $[14,20]$ used community based unannounced pill count and selfreport/ caregivers' report. A very significant difference was observed in both type of measurement in one study [14] that is $93.5 \%$ by caregivers report versus $34.8 \%$ by community based unannounced pill count.

In most cases adherence was defined whether a dose of a drug is taken or not. However in two of the included studies [15,17] adherence was defined in broader concept considering whether the medication was taken in the right time and the dietary restriction was followed. The two studies have reported dose adherence, time adherence, food adherence and overall adherence. Combined indicator of adherence was made using the three adherence measures taking into account all questions pertaining adherence. This is strict operational definition of adherence used by two of the reviewed studies.

\section{Facilitators and Barriers of adherence in Ethiopian HIV-positive patients}

Social support was a positive predictor of adherence in 3 studies $[15,17,22]$. Other positive predictors of adherence to HAART in Ethiopian HIV-positive patients includes: adherence counseling [27], use of memory aids [17], being on co-trimoxazole medication, for children not knowing one's own sero-status and being unaware caregiver's health problem [18], being married or being married caregivers $[14,20]$, caregiver formal education and caregiver's ability to identify ARV drug correctly [27], initiation while stage III/IV[14], trust in the effects of antiretroviral drugs, and trust in the quality of counseling [23].

Depression was a reported as negative predictor of adherence in 5 studies $[12,13,17,22,27]$. Substance use in general [27], alcohol drinking[13,20], D4T-3TC-NVP, AZT-3TC-NVP regimens [14,20], Stigma and discrimination[13,18], dosing three times daily regimens[20], Heavy pill burden[18], cost and access to transportation (economic problems) [18,23], lack of nutritional support [18,22], adverse effects $[12,16]$ were negative predictors of adherence to HAART in Ethiopian HIV-positive patients. Details of the facilitators and barriers of adherence to HAART in Ethiopian HIV-positive patients were summarized in Table 2.

Reasons claimed by participants for missing doses include forgetting [14,17,19-21,25], being ill [2], being busy [2,3,21,25] and running out of medication [15,19,22], being away from home $[21,23,25]$ and Lack of transport cost. For details of information refer Table 2.

\section{Discussion}

Several important insights have emerged from this study. Adherence improvement interventions and studies can benefit from these insights. Seventeen studies assessing adherence rate and/or determinants to HAART in Ethiopia HIV-Positive patients were identified by electronic and manual search of published literature. Thirteen studies on adults while 4 studies were on children. All of the 
Citation: Serawit Deyno, Alemayehu Toma (2014) Adherence to Antiretroviral Therapy in HIV-Positive Patients in Ethiopia: Review. J Trop Dis 2: 142. doi:10.4172/2329-891X.1000142

Page 3 of 7

studies used homogeneous cut off greater 95\% dose taking of monthly medication as operational definition of adherence.

One study used prospective study design while the others used cross-sectional study design. Amberibir and his coworkers used a three month prospective study design, data being collected at the first and third month. The available studies on adherence to HAART from the lowest level (cross-sectional study) design. Limited number and poor quality (cross-sectional) of the studies makes rates and determinants of adherence in Ethiopia unexplored yet. It can be perceived from these facts that adherence and its determinants in Ethiopian HIV-positive population are poorly defined.

\begin{tabular}{|c|c|c|c|c|c|}
\hline & Study & Total no of participant & Study design & Statistical analysis & Adherence measurement \\
\hline 1 & $\begin{array}{l}\text { Amberbir et al. } \\
{[17]}\end{array}$ & 400 adult & $\begin{array}{l}\text { Prospective } \quad \text { cross- } \\
\text { sectional }\end{array}$ & $\begin{array}{l}\text { Descriptive, bivariate, and } \\
\text { multivariate analyses using } \\
\text { SPSS }\end{array}$ & Self-report \\
\hline 2 & Azmeraw [27] & 204 children & cross-sectional & $\begin{array}{l}\text { Descriptive, bivariate, and } \\
\text { multivariate analyses using } \\
\text { SPSS }\end{array}$ & $\begin{array}{l}\text { Caregivers' } \\
\text { report }\end{array}$ \\
\hline 3 & Beyene et al. [20] & 422 adult & $\begin{array}{l}\text { Cross-sectional (qualitative } \\
\text { and quantitative) }\end{array}$ & $\begin{array}{l}\text { Descriptive, bivariate, and } \\
\text { multivariate analyses using } \\
\text { SPSS } 11.05\end{array}$ & $\begin{array}{l}\text { Self-report unannounced pill } \\
\text { count }\end{array}$ \\
\hline 4 & Biadigilin et al. [18] & 390 children respondents & $\begin{array}{l}\text { Facility-based } \\
\text { sectional }\end{array}$ & $\begin{array}{l}\text { Descriptive, bivariate, and } \\
\text { multivariate analyses using } \\
\text { SPSS 12.0.1 }\end{array}$ & $\begin{array}{l}\text { Caregivers' } \\
\text { report }\end{array}$ \\
\hline 5 & Biadigilin et al. & $\begin{array}{l}\text { Twelve caregivers and } 14 \text { key informants in } \\
\text { five hospitals }\end{array}$ & Qualitative study & NA & NA \\
\hline 6 & Giday [19] & 510 adults & cross sectional & $\begin{array}{l}\begin{array}{l}\text { Descriptive, } \\
\text { analyses using }\end{array} \\
\text { SPSS } 15.0\end{array}$ & Self-report \\
\hline 7 & Gusdal et al. & 79 patients, 17 peer counselors,22provider & Qualitative study & NA & NA \\
\hline 8 & Kebede et al. & 296 patients & cross-sectional study & $\begin{array}{l}\begin{array}{l}\text { Descriptive, } \\
\text { analyses using }\end{array} \\
\text { SPSS }\end{array}$ & Self-report \\
\hline 9 & Tadios [12] & 431 patients & Cross-sectional & $\begin{array}{l}\begin{array}{l}\text { Descriptive, } \\
\text { analyses using }\end{array} \\
\text { SPSS }\end{array}$ & Self-report \\
\hline 10 & $\begin{array}{l}\text { Tessema et al. } \\
{[16]}\end{array}$ & 504 study subjects & Cross-sectional & $\begin{array}{l}\text { Descriptive, } \\
\text { analyses using } \\
\text { SPSS }\end{array}$ & Self-report \\
\hline 11 & Tiyou et al. [15] & 319 adult PLWHA & $\begin{array}{l}\text { Facility based cross- } \\
\text { sectional }\end{array}$ & $\begin{array}{l}\begin{array}{l}\text { Descriptive, } \\
\text { analyses using }\end{array} \\
\text { SPSS 16.0 }\end{array}$ & Self-report \\
\hline 12 & Markos et al. [21] & 391 adult patients & Cross-sectional survey & $\begin{array}{l}\text { Descriptive, multiple logistic } \\
\text { rgression, analyses using } \\
\text { SPSS } 16.0\end{array}$ & $\begin{array}{l}\text { Interview, pill count, } \\
\text { and record review }\end{array}$ \\
\hline 13 & Negash & 355 adult patients & Cross-sectional survey & & \\
\hline 14 & $\begin{array}{l}\text { Biressaw et al. } \\
{[14]}\end{array}$ & 210 children & $\begin{array}{l}\text { Quantitative descriptive } \\
\text { design }\end{array}$ & $\begin{array}{l}\text { Descriptive, Chi-square test } \\
\text { and Multivariate logistic } \\
\text { regression analyses using } \\
\text { SPSS } 16.0\end{array}$ & $\begin{array}{l}\text { Caregivers report and } \\
\text { unannounced home-based pill } \\
\text { count }\end{array}$ \\
\hline 15 & Alagaw [22] & 357 adults & Cross-sectional survey & $\begin{array}{ll}\begin{array}{l}\text { Descriptive, } \\
\text { analyses using }\end{array} & \text { bivariate, } \\
\text { SPSS } 16.0 & \end{array}$ & Self-report \\
\hline
\end{tabular}

Table 1: Characteristics of adherence to HAARRT studies conducted in Ethiopia; NA= not applicable. 
Citation: Serawit Deyno, Alemayehu Toma (2014) Adherence to Antiretroviral Therapy in HIV-Positive Patients in Ethiopia: Review. J Trop Dis 2: 142. doi:10.4172/2329-891X.1000142

Page 4 of 7

\begin{tabular}{|c|c|c|c|c|}
\hline No & Study & Adherence rate & Determinants of Adherence & Reasons for missing doses \\
\hline $1 \mathrm{~A}$ & Amberbir et al. [17] & $\begin{array}{l}\mathrm{DA}=94.3 \% \\
\mathrm{TA}=97.2 \% \\
\mathrm{FA}=84.5 \% \mathrm{OA}=75.7 \%\end{array}$ & $\begin{array}{l}\text { Social support was positive } \\
\text { predictors while } \\
\text { depression was negative } \\
\text { predictors }\end{array}$ & $\begin{array}{l}\text { Forgetting, feeling sick or ill, } \\
\text { being busy and running out of } \\
\text { medication }\end{array}$ \\
\hline 1B & Amberbir et al.[17] & $\begin{array}{l}\mathrm{DA}=92.3 \%, \mathrm{TA}=97.4 \% \\
\mathrm{FA}=83.3 \% \\
\mathrm{OA}=72.7 \%\end{array}$ & $\begin{array}{l}\text { Social support and } \\
\text { use of memory aids were } \\
\text { positive predictors } \\
\text { while depression was negative } \\
\text { predictors }\end{array}$ & $\begin{array}{l}\text { forgetting, feeling sick or ill, } \\
\text { being busy and running out of } \\
\text { medication }\end{array}$ \\
\hline 2 & Azmeraw et al. [27] & $\mathrm{OA}=80.9 \%$ & $\begin{array}{l}\text { Adherence counseling, } \\
\text { caregiver formal education, and } \\
\text { caregiver's ability to identify } \\
\text { ARV drug correctly were } \\
\text { positive predictors while care } \\
\text { giver substance use and } \\
\text { depression were negative } \\
\text { predictors. }\end{array}$ & Not reported \\
\hline 3 & Beyene et al. [20] & $\begin{array}{l}\text { AS }=93.1 \% \\
\text { AUPC }=88.1 \%\end{array}$ & $\begin{array}{l}\text { Being unmarried, } \\
\text { unemployment; failure to } \\
\text { disclose HIV status, lack of } \\
\text { support from family, alcohol } \\
\text { drinking, treatment regimen } \\
\text { D4\&-3TC-NVP and AZT-3TC- } \\
\text { NVP, and dosing three times } \\
\text { daily regimens were negative } \\
\text { predictors }\end{array}$ & Transport cost and lack of food \\
\hline 4 & Biadgilign et al. [18] & $O A=91 \%$ & $\begin{array}{l}\text { Not paying a fee for treatment, } \\
\text { children who had ever received } \\
\text { any nutritional support from the } \\
\text { clinic were less likely to adhere. } \\
\text { Being on co-trimoxazole } \\
\text { medication, not knowing one's } \\
\text { own sero-status, and children } \\
\text { who were not aware of their } \\
\text { caregiver's health problem } \\
\text { were more likely to adhere }\end{array}$ & Not reported \\
\hline 5 & Biadgilign et al.[28] & NA & $\begin{array}{l}\text { Heavy pill burden, fear of } \\
\text { stigma and discrimination, cost } \\
\text { and access to transportation, } \\
\text { lack of understanding of the } \\
\text { benefit of taking the } \\
\text { medication, economic } \\
\text { problems in the household, and } \\
\text { lack of nutritional support were } \\
\text { the barriers }\end{array}$ & - \\
\hline 6 & Giday et al. [19] & $\mathrm{OA}=88.2 \%$ & $\begin{array}{l}\text { Inadequate lowerence } \\
\text { counseling, low level of } \\
\text { knowledge, and absence of job } \\
\text { were negative predictors }\end{array}$ & $\begin{array}{l}\text { Running out of medication, } \\
\text { forgetting, gastrointestinal } \\
\text { symptoms, giving priority for } \\
\text { praying, being hopeless }\end{array}$ \\
\hline 7 & Gusdal et al. [23] & NR & $\begin{array}{l}\text { Difficulties in supporting } \\
\text { themselves, transport cost, } \\
\text { opportunistic infection } \\
\text { treatment, and expensive } \\
\text { referrals to other hospitals were } \\
\text { barriers while trust in the } \\
\text { effects of ARV and in the } \\
\text { quality of counseling were } \\
\text { facilitators }\end{array}$ & NR \\
\hline 8 & Kebede et al. [25] & $O A=95.8 \%$ & $\begin{array}{l}\text { Good educational status were } \\
\text { positive predictor }\end{array}$ & $\begin{array}{l}\text { lack of money for transport, } \\
\text { and forgetting }\end{array}$ \\
\hline
\end{tabular}




\begin{tabular}{|c|c|c|c|c|}
\hline 9 & Tadios et al. [12] & $O A=81.2 \%$ & $\begin{array}{l}\text { Regular follow-up, not being } \\
\text { depressed having no side } \\
\text { effects, regimen fitting daily } \\
\text { routine and satisfaction with the } \\
\text { relationship with doctors were } \\
\text { positive predictors }\end{array}$ & $\begin{array}{l}\text { Being too busy, forgetting and } \\
\text { being away from home }\end{array}$ \\
\hline 10 & Tessema et al. [16] & $O A=82.7 \%$ & $\begin{array}{l}\text { Adverse effects, unwillingness } \\
\text { to disclose HIV status }\end{array}$ & - \\
\hline 11 & Tiyou et al. [15] & $\begin{array}{l}\mathrm{DA}=95 \% \\
\mathrm{FA}=89.7 \% \\
\mathrm{TA}=95 \% \\
\mathrm{OA}=72.4 \%\end{array}$ & $\begin{array}{l}\text { Family support were an } \\
\text { independent predictor }\end{array}$ & $\begin{array}{l}\text { Running out of medication, } \\
\text { being away from home and } \\
\text { being busy }\end{array}$ \\
\hline 12 & Markos et al.[21] & $\mathrm{OA}=74.2 \%$ & $\begin{array}{l}\text { Presence of symptoms in the } \\
\text { past month, distance of } \\
\text { residence, and presence of } \\
\text { dependents }\end{array}$ & $\begin{array}{l}\text { Being busy, } \\
\text { Forgetting, change in daily } \\
\text { routine and being away from } \\
\text { home }\end{array}$ \\
\hline 13 & Negashet al. [13] & NR & $\begin{array}{l}\text { Stigma, discrimination, } \\
\text { depression, and alcohol use } \\
\text { negatively affected }\end{array}$ & \\
\hline 14 & Biressaw et al. [14] & ACR $=93.5 \%, A U P C=34.8 \%$ & $\begin{array}{l}\text { Married caregivers and stage } \\
\text { III/IV are positive predictors } \\
\text { while } \\
\text { D4T+3TC+EFV } \\
\text { negative predictor }\end{array}$ & $\begin{array}{l}\text { Forgetfulness and } \\
\text { Child refusal }\end{array}$ \\
\hline 15 & Alagaw et al. [22] & $74.4 \%$ & $\begin{array}{l}\text { Living with supporter was } \\
\text { positive predictor while } \\
\text { depression and Inadequate diet } \\
\text { were negative predictors }\end{array}$ & $\begin{array}{l}\text { Toxicity, forgetting, illness, } \\
\text { Running out of medication, } \\
\text { Lack of transport cost, and lack } \\
\text { of food }\end{array}$ \\
\hline
\end{tabular}

Table 2: Rate and determinants of Adherence to HAART studies conducted in HIV-positive patients in Ethiopia; DA= dose adherence, TA= Time adherence, $\mathrm{FA}=$ food adherence, $\mathrm{OA}=$ Overall adherence, $\mathrm{UAPC}=$ unannounced pill count, $\mathrm{ACR}=\mathrm{NR}=$ not reported

Discrepant finding were observed among and within studies in adherence rate measurement. Within study variation occurs when a study uses more than outcome (adherence) measurement methods. Self-report measured adherence were $93.1 \%$ while unannounced pill count were $88.1 \%$ in study conducted in selected hospitals in south and central Ethiopia[20] and caregivers report adherence rate was 93.5\% while unannounced pill count was $34.8 \%$ in children adherence study [14]. It is clear from this studies that adherence measures vary with method of adherence measurement used.

Self-reported adherences to HAART in Ethiopian HIV-positive patients were greater than some of developed countries report [29,30]. Adherence rate to HAART in Ethiopia vary from the lowest $34.8 \%$ [14] to the highest $95.8 \%$ [25]. The major distinction between the two is that the former used objective adherence measurement (unannounced community based pill count) while the latter used caregivers report (a subjective measure). All most all adherence studies in Ethiopia used subjective measure of adherence measurement: selfreport for adults while caregivers report for children. This method has been shown to overestimate adherence both in the HIV setting and non-HIV setting and non-consistent results were found when compared to more objective measures [14, 31].

The level of adherence varies not only with patient but also with the type of adherence measurement used. The methods of adherence measurement includes: pharmacy refill record, pill counts, medication event monitoring (MEMs), viral load measurement, CD4 count and self-report. Because of their low cost and easy implementation selfreport and pill counts are widely used in developing country [32]. However self-report is prone to recall biases and sometimes may report exaggerated adherence and heavily depends on how the interview was made. Yet, self-reported adherence correlates with both viral load and clinical outcomes in some studies [33,34]. Except two studies [15,17] all other studies have measured adherence using only dose adherence.

Best adherence measurement has to assess whether or not dose is skipped, maintaining the scheduled time and food or dietary instructions agreed with the health provider to get the overall adherence rate. Therefore most of the studies conducted in Ethiopian HIV-positive patients narrowed adherence definition into taking a dose of medication or not. This kind of adherence definition lacks practical significance: for example not following dietary restriction which may decrease the blood concentration of the drug [35].

Social support was most commonly cited facilitator of adherence in most of the reviewed studies while failure to disclose sero-status was cited as negative predictor of adherence. The two parameters are linked as if one cannot disclose his/her sero-status it is impossible for $\mathrm{him} / \mathrm{her}$ to get social support. It is very crucial during initiation to encourage the patients to disclose their sero-status to relatives.

Depression was negative predictor of adherence in five reviewed studies. This can be avoided by providing necessary knowledge of how to live with HIV/AIDS. Encouragement and providing social support 
through community worker can alleviate the depression problem and finally improve adherence [36]. Antidepressants medications are also used in most studies to alleviate the depression and this treatment has increased the adherence to HAART [37-39]. In some studies no such association has been elucidated [40].

No interventional study had been conducted in Ethiopia setting. A prospective study design was used only by one study [17] which has one month duration. Because of this rate and determinants of HAART adherence in Ethiopia is yet poorly defined. We are looking forward for the evidence from one study which is powered to determine predictors of adherence using prospective study design of one year duration. The study protocol was published which has the aim to investigate the level of adherence to ART and a wide range of potential influencing factors, including adverse drug reactions occurring with ART. The primary outcome of the study will be the proportion of patients who are adherent to their ART regimen at 3,6 and 12 months using pill count [41].

\section{Conclusion and Recommendation}

Almost all of adherence to HAART studies conducted in Ethiopia used cross-sectional study design with self-report as adherence measurement. Though from poor evidence study design, adherence rate to HAART in Ethiopian HIV-positive patients were better than some developed countries report. Positive predictors of adherence in Ethiopia include Social support, adherence counseling, and use of memory aids while negative predictors' include: depression, substance use, alcohol drinking, stigma and discrimination, dosing three times daily regimens, heavy pill burden, cost and access to transportation (economic problems), lack of nutritional support, and adverse effects.

Adherence rate and its determinants in Ethiopian HIV-positive population was explained/studied poorly. Further studies have to be conducted which uses prospective cohort Interventional study design and varying methods of adherence measurement. The interventional study design has to test the effectiveness of the use of reminder devices (pillbox, alarms, mobile phone, text messages, peer support, treatment with antidepressants, counseling, food rations, delivering ART in to communities, and income generating activities.

\section{References}

1. Palella FJ Jr, Delaney KM, Moorman AC, Loveless MO, Fuhrer J, et al. (1998) Declining morbidity and mortality among patients with advanced human immunodeficiency virus infection. HIV Outpatient Study Investigators. N Engl J Med 338: 853-860.

2. Hogg RS, Yip B, Kully C, Craib KJ, O'Shaughnessy MV, et al. (1999) Improved survival among HIV-infected patients after initiation of tripledrug antiretroviral regimens. CMAJ 160: 659-665.

3. Chan KC, Wong KH, Lee SS (2006) Universal decline in mortality in patients with advanced HIV-1 disease in various demographic subpopulations after the introduction of HAART in Hong Kong, from 1993 to 2002. HIV Med 7: 186-192.

4. Jerene D, Naess A, Lindtjørn B (2006) Antiretroviral therapy at a district hospital in Ethiopia prevents death and tuberculosis in a cohort of HIV patients. AIDS Res Ther 3: 10 .

5. Benjamin H Chi, Ronald A Cantrell, Isaac Zulu, Lloyd B Mulenga, Jens W Levy, et al. (2009) Adherence to first-line antiretroviral therapy affects non-virologic outcomes among patients on treatment for more than 12 months in Lusaka, Zambia. Int J Epidemiol 38: 746-756.

6. Skogmar S, Schön T, Balcha TT, Jemal ZH, Tibesso G, et al. (2013) CD4 cell levels during treatment for tuberculosis (TB) in Ethiopian adults and clinical markers associated with CD4 lymphocytopenia. PLoS One 8: e83270.

7. Memirie ST (2009) Clinical outcome of children on HAART at police referral hospital, Addis Ababa, Ethiopia. Ethiop Med J 47: 159-164.

8. Balcha TT, Jeppsson A (2010) Outcomes of antiretroviral treatment: a comparison between hospitals and health centers in Ethiopia. J Int Assoc Physicians AIDS Care (Chic) 9: 318-324.

9. WHO (2003) Adherence to long-term therapy. Evidence for action. Geneva.

10. Xing H, Ruan Y, Li J, Shang H, Zhong P, et al. (2013) HIV drug resistance and its impact on antiretroviral therapy in Chinese HIVinfected patients. PLoS One 8: e54917.

11. Sears K, Scobie A, Mackinnon NJ (2012) Patient-related risk factors for self-reported medication errors in hospital and community settings in 8 countries. Can Pharm J (Ott) 145: 88-93.

12. Tadios Y, Davey G (2006) Antiretroviral treatment adherence and its correlates in Addis Ababa, Ethiopia. Ethiop Med J 44: 237-244.

13. Negash T, Ehlers V (2013) Personal factors influencing patients' adherence to ART in Addis Ababa, Ethiopia. J Assoc Nurses AIDS Care 24: 530-538.

14. Biressaw S, Abegaz WE, Abebe M, Taye WA, Belay M (2013) Adherence to Antiretroviral Therapy and associated factors among HIV infected children in Ethiopia: unannounced home-based pill count versus caregivers' report. BMC Pediatr 13: 132.

15. Tiyou A, Belachew T, Alemseged F, Biadgilign S (2010) Predictors of adherence to antiretroviral therapy among people living with HIV/AIDS in resource-limited setting of southwest ethiopia. AIDS Res Ther 7: 39.

16. Tessema B, Biadglegne F, Mulu A, Getachew A, Emmrich F, et al. (2010) Magnitude and determinants of nonadherence and nonreadiness to highly active antiretroviral therapy among people living with HIV/AIDS in Northwest Ethiopia: a cross-sectional study. AIDS Res Ther 7: 2.

17. Amberbir A, Woldemichael K, Getachew S, Girma B, Deribe K (2008) Predictors of adherence to antiretroviral therapy among HIV-infected persons: a prospective study in Southwest Ethiopia. BMC Public Health 8: 265 .

18. Biadgilign S, Deribew A, Amberbir A, Deribe K (2008) Adherence to highly active antiretroviral therapy and its correlates among HIV infected pediatric patients in Ethiopia. BMC Pediatr 8: 53.

19. Giday A, Shiferaw W (2010) Factors affecting adherence of antiretroviral treatment among AIDS patients in an Ethiopian tertiary university teaching hospital. Ethiop Med J 48: 187-194.

20. Beyene KA, Gedif T, Gebre-Mariam T, Engidawork E (2009) Highly active antiretroviral therapy adherence and its determinants in selected hospitals from south and central Ethiopia. Pharmacoepidemiol Drug Saf 18: $1007-1015$

21. Markos E, Worku A, Davey G (2008) Adherence to ART in PLWHA at Yirgalem Hospital, South Ethiopia. Ethiop J Health Dev 22: 174-179.

22. Alagaw A GW, Taha M, Dejene T (2013) Factors Associated with Antiretroviral Treatment Adherence among Adult Patients in WolaitaSoddo. J Trop Dis 1: 125.

23. Gusdal AK, Obua C, Andualem T, Wahlstrom R, Tomson G, et al. (2009) Voices on adherence to ART in Ethiopia and Uganda: a matter of choice or simply not an option? AIDS Care 21: 1381-1387.

24. Chalker JC, Andualem T, Gitau LN, Ntaganira J, Obua C, et al. (2010) Measuring adherence to antiretroviral treatment in resource-poor settings: the feasibility of collecting routine data for key indicators. BMC Health Serv Res 10: 43.

25. Kebede A, Wabe NT (2012) Medication adherence and its determinants among patients on concomitant tuberculosis and antiretroviral therapy in South west ethiopia. N Am J Med Sci 4: 67-71.

26. Balcha TT, Jeppsson A, Bekele A (2011) Barriers to antiretroviral treatment in ethiopia: a qualitative study. J Int Assoc Physicians AIDS Care (Chic) 10: 119-125. 
Citation: Serawit Deyno, Alemayehu Toma (2014) Adherence to Antiretroviral Therapy in HIV-Positive Patients in Ethiopia: Review. J Trop Dis 2: 142. doi:10.4172/2329-891X.1000142

Page 7 of 7

27. Azmeraw D, Wasie B (2012) Factors associated with adherence to highly active antiretroviral therapy among children in two referral hospitals, northwest Ethiopia. Ethiop Med J 50: 115-124.

28. Biadgilign S, Deribew A, Amberbir A, Deribe K (2009) Barriers and facilitators to antiretroviral medication adherence among HIV-infected paediatric patients in Ethiopia: A qualitative study. SAHARA J 6: 148-154.

29. Simoni JM, Montgomery A, Martin E, New M, Demas PA, et al. (2007) Adherence to antiretroviral therapy for pediatric HIV infection: a qualitative systematic review with recommendations for research and clinical management. Pediatrics 119: e1371-1383.

30. Sellier P, Clevenbergh P, Ljubicic L, Simoneau G, Evans J, et al. (2006) Comparative evaluation of adherence to antiretroviral therapy in sub Saharan African native HIV-infected patients in France and Africa. Clin Infect Dis 43: 654-657.

31. Duong M, Piroth L, Grappin M, Forte F, Peytavin G (2001) Evaluation of the Patient Medication Adherence Questionnaire as a tool for selfreported adherence assessment in HIV-infected patients on antiretroviral regimens. HIV Clinical Trials 2: 128-135.

32. Nachega JB, Mills EJ, Schechter M (2010) Antiretroviral therapy adherence and retention in care in middle-income and low-income countries: current status of knowledge and research priorities. CurrOpin HIV AIDS 5: 70-77.

33. Liu H, Golin CE, Miller LG, Hays RD, Beck CK, et al. (2001) A comparison study of multiple measures of adherence to HIV protease inhibitors. Ann Intern Med 134: 968-977.

34. Nieuwkerk PT, Oort FJ (2005) Self-reported adherence to antiretroviral therapy for HIV-1 infection and virologic treatment response: a metaanalysis. J Acquir Immune DeficSyndr 38: 445-448.
35. Stellbrink HJ, Arastéh K, Schürmann D, Stephan C, Dierynck I, et al. (2014) Antiviral activity, pharmacokinetics, and safety of the HIV-1 protease inhibitor TMC31091, coadministered with ritonavir, in treatment-naive HIV-1-infected patients. J Acquir Immune DeficSyndr 65: 283-289.

36. Degroote S, Vogelaers D, Vermeir P, Mariman A, De Rick A, et al. (2014) Determinants of adherence in a cohort of Belgian HIV patients: a pilot study. ActaClinBelg 69: 111-115.

37. Bottonari KA, Tripathi SP, Fortney JC, Curran G, Rimland D, et al. (2012) Correlates of antiretroviral and antidepressant adherence among depressed HIV-infected patients. AIDS Patient Care STDS 26: 265-273.

38. Walkup J, Wei W, Sambamoorthi U, Crystal S (2008) Antidepressant treatment and adherence to combination antiretroviral therapy among patients with AIDS and diagnosed depression. Psychiatr Q 79: 43-53.

39. Horberg MA, Silverberg MJ, Hurley LB, Towner WJ, Klein DB, et al. (2008) Effects of depression and selective serotonin reuptake inhibitor use on adherence to highly active antiretroviral therapy and on clinical outcomes in HIV-infected patients. J Acquir Immune DeficSyndr 47:384-390.

40. Akincigil A, Wilson IB, Walkup JT, Siegel MJ, Huang C, et al. (2011) Antidepressant treatment and adherence to antiretroviral medications among privately insured persons with HIV/AIDS. AIDS Behav 15: 1819-1828.

41. Bezabhe WM, Peterson GM, Bereznicki L, Chalmers L, Gee P (2013) Adherence to antiretroviral drug therapy in adult patients who are HIVpositive in Northwest Ethiopia: a study protocol. BMJ Open 3: e003559. 